\title{
The Use of Authentic Materials in Teaching Reading to Secondary School Students in Malaysia: A Literature Review
}

\author{
Radmila Ronios Mara, Maslawati Mohamad \\ Universiti Kebangsaan Malaysia (UKM), Bangi, Selangor, Malaysia \\ Email: milamieara94@gmail.com,maslawati@ukm.edu.my
}

How to cite this paper: Mara, R. R., \& Mohamad, M. (2021). The Use of Authentic Materials in Teaching Reading to Secondary School Students in Malaysia: A Literature Review. Creative Education, 12, 1692-1701.

https://doi.org/10.4236/ce.2021.127129

Received: June 25, 2021

Accepted: July 24, 2021

Published: July 27, 2021

Copyright $\odot 2021$ by author(s) and Scientific Research Publishing Inc. This work is licensed under the Creative Commons Attribution International License (CC BY 4.0).

http://creativecommons.org/licenses/by/4.0/

\section{(c) (i) Open Access}

\begin{abstract}
English language has been used globally. In Malaysia, to strengthen the English proficiency among the Malaysian students, English language is introduced as a compulsory subject at both primary and secondary schools and administered under the language education policy. Students in secondary school must learn the language for the sake of their future endeavours. As teachers, it is their role to grab the students' attention to learn English language through reading. However, most of the students nowadays never show the interest to read. Various kinds of authentic materials could be used to help the students in their language acquisition and to bridge the gap between classroom knowledge and students' capacity to participate in the real-world situation. Prior to this, the researcher finds that authentic materials are useful in enhancing the secondary school students to read and help the students to explore more knowledge from this borderless world. In accordance to encourage the students in secondary school to read, this review will expose the readers to the use of authentic materials in teaching reading, the roles of authentic materials in developing the reading skill among the secondary students, and the teachers' role in teaching reading by using the authentic materials. Most of the findings have shown that authentic materials give positive impacts to the secondary school students to improve their reading skill. In short, the more materials the students read, the more knowledgeable they will become.
\end{abstract}

\section{Keywords}

Authentic Materials, Reading Skills, Secondary School Students

\section{Introduction}

Most students nowadays have shown their lack of interest in reading English 
language materials. Reading interest is important in encouraging the students to read (Khairuddin, 2013 cited in Romdanih \& Yuningsih, 2021) because students who cannot read would not be able to succeed in school and life (Delattre, 2005; Khairuddin, 2013 cited in Romdanih \& Yuningsih, 2021). Baba and Affendi, 2020 mentioned that the ability to read is crucial in which reading affects an individual's intellectual and emotional growth. As the result, good readers would have more chances in broadening their mental horizons and better opportunities of success. Students who seldom read would encounter problem(s) in knowing the progress happening around them. Reading is not only reading the words, but it requires a process of interaction between the students' prior knowledge, language proficiency, understanding the real meaning and information encoded in the text. If the students do not practice themselves to read, they would fail to grasp the content and structure of the text (Ismael, 2021). In order to know the current issue, students need knowledge to obtain through reading including the materials that they could regard as their background for a start. After reading the information from the materials, the students would have mental process that requires the students to participate in the creation of meaning actively rather than passive skill (El-Dali, 2021). The students need to be exposed to something that would trigger the imagination and thinking. In relation to this, initial reading like reading a short passage is very effective for the students' first language learning. The rhetorical organization of a text interacts with the students' formal schemata. For instance, the background knowledge and experience with textual organization affect the reading comprehension. There are different measures of reading comprehension that are influenced by the text structure such as comprehension-written recall protocols, summaries, retellings, and questions-answering (Ramsa \& Rawian, 2021). Hence, the teachers' skills in accessing the students' strength, limitations, and in building strategies can shape the students' interest towards reading.

Good reading habit among the students could be inculcated if the English teachers impart relevant input in the teaching of reading. The teachers should encourage their students to read by introducing a pleasure reading to form a good reading habit that would then transcend into improved academic reading skill (Scott \& Saainman, 2016: 1 cited in Molotja \& Themane, 2018). The students as well should be well-informed that learning English is important especially in the education process. Regarding to this, the students must know on how to learn from reading. With a view to inculcate reading among the students, there are three types of reading namely, oral reading, extensive reading, and intensive reading (Jose and Raja, 2011 cited in Olifant et al., 2020). Students must learn English as a second language because it is a global language. As in the Malaysian Education Blueprint (2013-2025), the government has transformed the education system in Malaysia that is now essential to lead the Malaysian to meet the current and future needs both locally and globally (Ishak \& Mohamad, 2018). One of the most important skills to be assessed learning English as a sec- 
ond language is reading skill because the government desires to upgrade the students' English proficiency since reading has involved the process of decoding words in order to derive meaning (Floyd et al., 2007 cited in Woods, Niileksela, \& Floyd, 2021; Mohamad et al., 2015; Ishak \& Mohamad, 2018). So, reading skill does help the students to improve themselves in improving the level of proficiency in English language and enhance them to have the awareness on the importance of learning English as a second language.

In 2001, the Common European Framework of References (CEFR) has been formulated and designed for the purpose to establish the international standards for foreign language education to cater the needs of the students in academics and teaching and learning of the language (Uri \& Abd Aziz, 2018). CEFR has an extensive description of what the students in secondary school could do at six level of language skills; A1 and A2 are for the basic level, B1 and B2 are for the independent level and $\mathrm{C} 1$ and $\mathrm{C} 2$ are for the proficient level (Puteh-Behak et al., 2018). As in secondary school, the level of proficiency in reading is in the range of at least A1 to B2 level. The secondary textbooks have provided plenty of reading materials for the students to read and it is depending on the students' willingness to read. Hence, to align with the CEFR, it is important to realize that all the readers including ineffective readers, average readers, and proficient readers differ considerably in their interest, personalities and their choice of materials in the context in which the reading process occurs.

The use of authentic materials benefits the students that seems to be great to help them to improve their reading skills. Authentic materials create the interest of reading among the students and allow them to participate with more enthusiasm in reading. In schools, the authentic materials such as textbooks are effective to encourage the students to read according to their needs and requirements (Rao, 2019). Furthermore, Berardo (2006) as cited in Namaziandost et al. (2021) claims that the use of authentic materials benefits the students to expose themselves to the real language that has been used in real context. In addition, authentic materials help to motivate the students, giving the sense of achievement if the students understand what they have read and enhance the students to do further reading. For instance, reading story books, comics, magazines and newspapers.

In reviewing the past studies, Fitriana et al. (2019) concluded that the use of authentic materials has had the positive perception among the students in which reading using the authentic texts is very easy and at the same time, improves the students' reading comprehension. Thus, this paper aims to explore the use of authentic materials in teaching reading as a second language, the roles of authentic materials in developing reading and the teachers' role in teaching reading by using the authentic materials.

\section{The Use of Authentic Materials in Teaching Reading}

In Malaysia, English is known as a second language as stated in Article 152. Eng- 
lish has played an important role and is taught as a compulsory subject in both primary and secondary schools (Azmi, 2013 cited in Kamsin \& Mohamad, 2020). English is said to be a compulsory subject as it becomes more important in this globalized world and is used to be a medium of instruction in schools (Cheng et al., 2016). Ramiza and Albion (2013) as cited in Hussan Sahib \& Stapa (2021) also agreed that English language continues to be taught as a compulsory subject due to the evolution in Malaysian education system. However, not all Malaysian students could master the English language well and it is one of the most critical subjects. Several problems affect the students' learning English as a second language in Malaysia. Among those are because of their family environment that gives less support of encouragement, peer to peer learning and the interest towards the language itself. Due to this, the students are not able to learn the English language mainly in reading. This is because the students have low self-esteem in learning and demotivated (Nor et al., 2019). At this time, the English teachers should play their role to guide the students to learn English language through reading. Various strategies should be made, for instance, the teachers should provide sufficient reading materials and give ample practices to the students in order to get them fluent in reading (Nishanthi, 2018).

Reading is a process that involves word recognition, comprehension, fluency, and motivation. Reading is also a receptive psycholinguistic process in which the students create the meaning from the text read (Cekiso, 2017; Leipzig, 2001 and Goodman, 1988 cited in Cekiso, 2017). If the students are able to read, they are more than just being able to recognize the letters and decode words. Apart from that, reading the authentic materials helps the students to get familiar with various forms of the written text as well as the functions (Pretorius and Machet, 2004:45 cited in Cekiso, 2017). The familiarization with various forms of written text is a way to access the students' interest to seek for more informative information from the article read (Breidnstein, et al., 2012 cited in Holmes, 2020). The use of authentic materials to teach English language helps to develop the students' reading comprehension, absorb the information read, enable the students to set the study goals, and prompt the use of revision techniques (Qizi, 2021). Ameen and Kamal (2021) claim that, the use of authentic materials enhances the ability of the students to transfer what they learn inside the class to the outside world. Thus, reading various forms of authentic materials help the students demand a considerable language activation in which the students employ their brains using their knowledge in order to get the meaning of an utterance or text read (Vogel \& Loudova, 2014).

\section{The Roles of Authentic Materials in Developing Reading}

Authentic materials are defined as the printing materials, videos materials and audio materials that the students could encounter in their daily lives (Umirova, 2020). For instance, change-of-address forms, job applications, menus, voice mail messages, radio programs and videos. The authentic materials are not only 
specifically to be used in the classroom. The teachers could make various learning tools with the help of authentic materials for the students as the materials are authentic (Ianiro, 2007 as cited in Mahendra, Nitiasih, \& Saputra, 2018). Due to the complexity in vocabularies and structures, the authentic materials have been strongly debated and all these could be regarded as learning devices. Besides, it is also good for the students to improve their English language especially in reading skill (Ahmed et al., 2021; Khusniyah, 2021), for example, in the English secondary textbooks. There are various kinds of reading activities given in the textbooks the students could learn including learning the new grammars and vocabularies that suit their level and ability. On the other hand, the language used in the textbooks close the language gap between the classroom knowledge and real life. Regarding the requirement of the classroom knowledge, the language used in the textbooks is only valid in a classroom environment whereas in real life, the students have to deal with the language of brochures, office works, application forms and other cultural products. It is depending on the students themselves to read what kind of authentic materials they wish to read. So, teachers in schools must encourage the students to read for pleasure (Al Nabhani \& Al Azri, 2015).

In fact, authentic materials are abundant in Malaysia. The authentic materials used in class could be very useful tool to motivate the students and enable them to feel comfortable in learning the English language (Joraboyev, 2021). Therefore, students should be exposed to varieties of authentic reading materials of different text types. This would help to familiarize the students with the convention of text types appropriate to their needs. Initially, the roles of authentic materials could be only useful in the classroom in as much as they help the students to develop the required reading skill. The use of authentic materials in reading among the students could be useful as the students are introduced to real discourse such as in video interviews with famous people where intermediate students listen for gist and the reading text provide various patterns of reading text that are ideal to teach the mini-skill like scanning. Hence, to enhance the students to read, suitable strategies could be done to use the authentic materials in attracting the students' interest to read and learn the English language.

\section{The Teachers' Roles in Teaching Reading by Using Authentic Materials}

It is undeniable that the teachers play their vital role in encouraging the students towards reading the authentic materials. If the students are able to read and enjoy the reading activities conducted by their teachers, they would get motivated and putting more efforts to learn English language through reading with the help of authentic materials. Motivation is something related to the students' behaviours that they have to set their mind up to figure out certain work (Zaman, 2015). In Tu and Zhou (2015) as cited in Nguyen, Phan and Vu (2021), motivation is an essential aspect in language learning success. This is because learning is self-initiated, yet requires motivation in order to keep the students to engage 
in learning activities conducted by their teachers. It is so for learning English as a second language is something that is learnt especially among the non-native students. In this aspect, the teachers have to put more efforts in their teaching in order to encourage the students to read English language materials.

Teachers could emphasize the hands-on activities so that the students could have fun in reading the English materials. The teachers should aware on the current curriculum to make sure it is well-matched to the students' interests and abilities (Brophy, 2004 cited in Wentzel, 2020). In secondary schools, there are different levels of students' abilities in reading. Aligned with the CEFR context most of the students in secondary schools could not reach the B2 and C1 level of proficiency in reading. It is maybe because of the teachers' strategies that might not attract the students to learn reading. As the result, the students would get bored and easily feel demotivated. Hence, to get a better achievement in learning English as a second language among the secondary school students, the teachers should provide interesting reading materials with fun activities so that the students could enjoy the reading lesson. The teachers as well should make sure the students are ready to learn the English language. If the readiness of learning is at the higher level, there will be a higher level of attentiveness. As for the students' attitudes, generally, the students have positive attitudes towards English language learning (Pengwichai, 2021). Therefore, kudos must be given to the teachers for making their students able to read the English language reading materials.

Moreover, to get develop reading skill in the teaching of English language, the teachers should give their responsibilities to filter the materials used via the selection of the learning objectives (Spelleri, 2002 cited in Mestari \& Malabar, 2016; Mohammed, 2021; Khodabandeh \& Tahririan, 2020; Rehman \& Perveen, 2021) and conduct the activities for reading. In line with this, the teachers should set the target and inform the students that there will be a time limit for the students to read. The teachers need to observe the class when reading to see whether the students have enough time to read the reading materials (Harmer, 1991, p. 286 cited in Vogel \& Loudova, 2014).

In order to encourage the students to read English materials, the teachers could develop the interactive theories related to reading into their lesson such as schema theory. Schema theory depends on the fact that every act of comprehension involves one's knowledge. The schema theory is important in reading comprehension as it is used to guide the students to comprehend the written materials that provide the directions for the students to construct the meaning from their own understanding towards the knowledge (Ismael, 2021). By using schema theory, it helps the English teachers in secondary school to practice their students to digest the information and interpret the meanings in a relevant manner.

\section{Conclusion}

This study intends to focus and explore more on the use of authentic materials in teaching reading as a second language, the roles of the authentic materials in 
developing reading among the students and the teachers' roles in teaching reading by using authentic materials. The reviews have been made and most of the researchers in previous studies claim that authentic materials give positive impact to the students to improve their reading skill. English teachers should always be aware of their students' needs in reading in order to make sure they could be good reader in the future. For example, provide the ample reading materials to the students so that the students could gain a lot of vocabularies and learn the grammar types from the written text. In school, teachers should continue implementing the reading programmes such as the "NILAM Reading Programme" and personal observation towards the students' progress in reading ability. By doing so, it may help the students to instil the reading habit because they could see the number of books they have read.

Last but not least, the school teachers, parents and students should work hand in hand in order to produce competent students in the English language subject mainly in reading skill. Good rapport and teamwork among the teachers, students and parents would be recommended to this good deal. Reading culture should be developed both in school and at home. Perhaps nowadays, due to the modernisation that we are facing the teachers' role should be done by their parents at home and the teachers act as their guidance or moderator in school. In this sense, the educated parents may have the feeling of belonging in educating or rather imparting knowledge to their siblings at home. By doing so, hopefully the school's English language result could be gradually improved. In short, upon analysing all these consequences, the researcher feels that both teachers and parents are having an equal role in educating the students to improve their reading skill.

\section{Conflicts of Interest}

The authors declare no conflicts of interest regarding the publication of this paper.

\section{References}

Ahmed, A. A., Begum, G., Sabir, I. S., Atta, M., Umer, S., \& Bukhari, S. H. M. (2021). Using English Reader's Digest to Enhance Vocabulary of Pakistani Students at Tertiary Level: An Experimental Study. Multicultural Education, 7, 26.

Al Nabhani, S., \& Al Azri, R. (2015). The Importance of Authentic Reading Materials in the Development of Reading Skills of Grade Ten Students in the Government Schools of the Sultanate of Oman. International Journal of Scientific \& Technology Research, 4, 199-202.

Ameen, C. A. M., \& Kamal, L. R. (2021). The Perspectives of EFL Instructors on the Use of Authentic Materials in the Classroom: Charmo University as a Case Study. The Scientific Journal of Cihan University-Sulaimaniya, 5, 39-56.

Baba, J., \& Affendi, F. R. (2020). Reading Habit and Students' Attitudes towards Reading: A Study of Students in the Faculty of Education UiTM Puncak Alam. Asian Journal of University Education, 16, 109-122. https://doi.org/10.24191/ajue.v16i1.8988

Cekiso, M. (2017). Teachers' Perceptions of Reading Instruction in Selected Primary 
Schools in the Eastern Cape. Reading \& Writing, 8, 1-8. https://doi.org/10.4102/rw.v8i1.158

Cheng, L., Yunus, M. M., \& Mohamad, M. (2016). Issues Contributing to Low Performance of English in a National School in Song, Sarawak. Proceedings of the ICECRS, 1, 499-510. https://doi.org/10.21070/picecrs.v1i1.519

El-Dali, H. M. (2021). Insights into L2 Reading: The Effects of Content Knowledge on Reading Comprehension of Egyptian University Students. International Journal of Education \& Social Sciences (IJESS), 2, 113-125.

Fitriana, P., Hadijah, D., \& Lestari, Z. W. (2019). The Use of Authentic Material to Improve Students' Reading Comprehension. ELTIN Journal, Journal of English Language Teaching in Indonesia, 7, 8-11. https://doi.org/10.22460/eltin.v7i1.p8-11

Holmes, S. M. (2020). Instructional Leadership for Trauma Impacted Students Attending Transfer High Schools in New York City. Sage Graduate School.

Hussan Sahib, F., \& Stapa, M. (2021). Managing English Language Curriculum Reform in Malaysian Primary Schools Issues and Challenges. E-Proceedings of International Conference on Language, Education, Humanities \& Social Sciences (i-LEdHS2021), 464-476.

Ishak, W. I. W., \& Mohamad, M. (2018). The Implementation of Common European Framework of References (CEFR): What Are the Effects Towards LINUS Students' Achievements? Creative Education, 9, 2714-2731.

https://doi.org/10.4236/ce.2018.916205

Ismael, R. K. (2021). The Effect of Using Semantic Map Technique in Teaching Reading Comprehension on Students' Achievement. Al-Adab Journal, 2, 43-52. https://doi.org/10.31973/aj.v2i137.1186

Joraboyev, B. B. O. (2021). Using Authentic Materials on English Lessons. Academic Research in Educational Sciences, 2, 1018.

Kamsin, S. R., \& Mohamad, M. (2020). The Implementation of Highly Immersive Programme (HIP) Speaking Activities in Malaysian Schools: A Literature Review. Creative Education, 11, 1783. https://doi.org/10.4236/ce.2020.119130

Khodabandeh, F., \& Tahririan, M. H. (2020). Exploring the Impact of Blended, Flipped, and Traditional Teaching Strategies for Teaching Grammar on Iranian EFL Learners' through English Newspaper Articles. Journal of Teaching Language Skills, 39, 89-129.

Khusniyah, N. L. (2021) English Extensive Reading Material Needs in Digital Era. AL-ISHLAH: Jurnal Pendidikan, 13, 763-768. https://doi.org/10.35445/alishlah.v13i1.560

Mahendra, Y., Nitiasih, P. K., \& Saputra, I. N. P. H. (2018). An Analysis of Authentic Materials Used by Senior High School English Teachers in Singaraja. Jurnal Pendidikan Bahasa Inggris undiksha, 5.

Mestari, S. A., \& Malabar, F. (2016). The Use of Authentic Materials in Teaching Grammar for EFL Students (Teachers' Perspective). LLT Journal: A Journal on Language and Language Teaching, 19, 125-131. https://doi.org/10.24071/1lt.2016.190207

Mohamad, M., Hamdan, N. A., Shaharuddin, S., \& Khalid, F. (2015). Hypermedia Reading Strategies of TESL Undergraduate Students in Malaysia. Turkish Online Journal of Educational Technology, 2015, 301-310.

Mohammed, F. G. (2021). The Effects of Teaching Through Authentic Material on EFL Learners. Docens Series in Education, 1, 73-86.

Molotja, T. W., \& Themane, M. (2018). Enhancing Learners' Reading Habits through Reading Bags at Secondary Schools. Reading \& Writing, 9, 1-9. 
https://doi.org/10.4102/rw.v9i1.185

Namaziandost, E., Razmi, M. H., Ahmad Tilwani, S., \& Pourhosein Gilakjani, A. (2021). The Impact of Authentic Materials on Reading Comprehension, Motivation, and Anxiety among Iranian Male EFL Learners. Reading \& Writing Quarterly, 1-38. https://doi.org/10.1080/10573569.2021.1892001

Nguyen, L., Phan, H., \& Vu, M. H. V. (2021). Factors Influencing Vietnamese Children's Attitude towards Learning English as a Second Language. Oxford Journal of Technology, Arts, Sciences and Knowledge, 2, 1-25.

Nishanthi, R. (2018). The Importance of Learning English in Today World. International Journal of Trend in Scientific Research and Development, 3, 871-874. https://doi.org/10.31142/ijtsrd19061

Nor, K. M., Razali, M. M., Talib, N., Ahmad, N., Sakarji, S. R., Saferdin, W. A. A. W. M., \& Nor, A. M. (2019). Students' Problems in Learning English as a Second Language among MDAB Students at UITM Malacca. International Journal, 2, 1-12. https://doi.org/10.35631/ijhpl.27001

Olifant, T., Cekiso, M., Boakye, N., \& Madikiza, N. (2020). Investigating Reading Comprehension Strategies Used by Teachers during English First Additional Language Reading Instruction. Journal for Language Teaching, 54, 71-93.

https://doi.org/10.4314/jlt.v54i2.4

Pengwichai, C. (2021). Thai EFL Students' Attitudes towards English Language Learning: A Case Study of Weekend Non-English Major Students at Phranakhon Rajabhat University. Academic Journal Phranakhon Rajabhat University, 12, 88-103.

Puteh-Behak, F., Zakaria, Z. A., Adnan, J. N., Darmi, R., Saad, N. S. M., \& Abdullah, N. (2018). Teachers' Insights on the Students' ESL Reading Comprehension Performance Based on CEFR: A Case Study in Malaysia. Advanced Science Letters, 24, 2701-2705. https://doi.org/10.1166/asl.2018.11039

Qizi, E. M. B. (2021). The Contemporary Methods of Teaching Reading Using Authentic Materials. 7th Global Congress on Contemporary Sciences \& Advancements, New York, 25 June 2021, 86-91.

Ramsa, N. I. B., \& Rawian, R. M. (2021). A Review on Systematic Guided Reading Strategies and Its Implication on Reading Comprehension. International Journal of Academic Research in Business \& Social Sciences, 11, 203-215.

Rao, P. S. (2019). The Effective Use of Authentic Materials in the English Language Classrooms. Humanities, 7, 1-8. https://doi.org/10.34293/sijash.v7i1.556

Rehman, A., \& Perveen, A. (2021). Teachers' Perceptions about the Use of Authentic Material in Pakistani EFL Classrooms. International Journal of Language Education, 5, 63-73. https://doi.org/10.26858/ijole.v5i2.15241

Romdanih, R., \& Yuningsih, E. (2021). Integrating Fairy Tales into Reading Class: Do They Catch Young Learners' Reading Interest? Jurnal Ilmu Pendidikan (JIP) STKIP Kusuma Negara Jakarta, 12, 132-138. https://doi.org/10.37640/jip.v12i2.857

Umirova, D. (2020). Authenticity and Authentic Materials: History and Present. European Journal of Research and Reflection in Educational Sciences, 8, 129-133.

Uri, N. F. M., \& Abd Aziz, M. S. (2018). Implementation of CEFR in Malaysia: Teachers' Awareness and the Challenges. 3L: Language, Linguistics, Literature ${ }^{\circledR}, 24,168-183$. https://doi.org/10.17576/3L-2018-2403-13

Vogel, M. R., \& Loudova, M. K. (2014). The Use of Authentic Text in English Lessons. Diploma Thesis, Masaryk University.

Wentzel, K. R. (2020). Motivating Students to Learn. Routledge. 


\section{https://doi.org/10.4324/9780429027963}

Woods, I. L., Niileksela, C., \& Floyd, R. G. (2021). Do Cattell-Horn-Carroll Cognitive Abilities Predict Reading Achievement Similarly for Black Children as for Other Racal/Ethnic Groups? Contemporary School Psychology, 1-17. https://doi.org/10.1007/s40688-020-00338-1

Zaman, J. (2015). Role of Motivation in Second Language Learning: A Study of Private University Students in Bangladesh. Doctoral Dissertation, BRAC University. 